\title{
Examining Student Involvement in the Total Program in Small Schools in New Mexico
}

\author{
R. G. (Tre) Easterly III ${ }^{1}$, F. Hodnett ${ }^{2}$, M. Rodriguez ${ }^{3}$
}

\begin{abstract}
The dynamics facing rural development and school policy in New Mexico has limited merging and redistricting efforts in small schools in isolated rural communities. This has created a situation where small schools exist in several rural communities in the state. These programs often include schoolbased agricultural education as a program offering. The dynamics of the schools can impact how the total program approach commonly used in agricultural education can be implemented. The purpose of the study was to explore how agriculture teachers in small schools in New Mexico developed their own institutional polices and worked with the policies established by the school to involve students in the total program. A qualitative case study with six teachers was conducted. The themes emphasized the nuanced nature of the programs as well as the importance of relationships with students, parents, community members, and school staff to implement these programs. The teachers faced challenges related to balancing student time and working with athletics for scheduling. Successful programs cater to the context of the school and community by getting to know the students they serve. Advice and best practices provided by the teachers were discussed. Recommendations were provided related to establishing and maintaining relationships.
\end{abstract}

\section{Keywords}

Rural, school-based agricultural education, United States, case study

1. R. G. (Tre) Easterly III, Assistant Professor, University of Florida, 307C Rolfs Hall PO Box 110540, Gainesville, FL 32611-0540, tre.easterly@ufl.edu, (iD) https://orcid.org/0000-0003-2807-512X

2. Frank Hodnett, Professor, New Mexico State University, P.O. Box 30003, MSC 3501, Las Cruces, NM 88003 , fhodnett@nmsu.edu, ID https://orcid.org/0000-0002-3081-4342

3. Mary Rodriguez, Associate Professor, The Ohio State University, 2120 Fyffe Road, Columbus, Ohio 43210, Rodriguez.746@osu.edu, (iD) https://orcid.org/0000-0002-8716-2787 


\section{Introduction and Problem Statement}

The average student population size for high schools in the United States is 850 students. Over the last 50 years, school consolidation in the United States has caused this number to steadily increase. Schools with less than 300 secondary students attending school in a district make up less than $1 \%$ of schools (National Center for Educational Statistics, 2020). This novelty means issues surrounding small schools are not a common topic of research. In the Western United States, geographic isolation and large distances between programs prevent redistricting efforts. The results are schools that exist in small, rural towns with relatively low student populations (Lavalley, 2018). Rumberger and Thomas (2000) found larger school sizes led to higher dropout rates. However, there are some reports of " $U$ " shaped dropout trends with smaller schools having higher incidences of dropouts than moderately populated schools (Bradley \& Taylor, 1998; Foreman-Peck \& Foreman-Peck, 2006; Leithwood \& Jantzi, 2009; Sawkins, 2002).

For many of these programs in rural western towns, school-based agricultural education (SBAE) programs are a logical choice to include in the school curriculum because of the opportunities in the communities and interest of the students. SBAE programs are traditionally implemented using a total-program approach that includes involvement in classroom instruction, involvement in student organizations, and experience, workplace, or service learning through supervised agricultural experiences (Croom, 2008; National FFA Organization, n.d.). The execution of this model relies on student involvement beyond the time in the classroom (Talbert et al., 2014).

\section{Theoretical and Conceptual Framework}

Student involvement is essential for SBAE programs. Astin (1999) developed the student involvement theory to explain how students engage at secondary institutions. According to Astin, student involvement is the quantity and quality of the physical and psychological energy that student invest in an experience. By examining various aspects of student life such as living on campus, investment in coursework, interaction with faculty/staff, or being involved in campus student organizations, Astin was able to draw links between dropout rate and involvement. In the theory, student time is considered a resource students choose to devote to various activities. Astin postulated that institutional policies have an impact on how much time and energy students spend in pursuits that lead towards persistence in college. The theory states that the more a student is involved in the overall educational experience, the greater the amount of student learning and personal development (Astin, 1999).

For this study, we applied the student involvement theory as a frame through which to explore the small secondary schools. This study sought to examine how agriculture teachers in small schools structure their agricultural education programs and FFA chapters to utilize the resource of student time most effectively. Students have a limit on their time and energy to be involved. Further, students balance their investments between family, friends, jobs, and other outside factors. Students in agricultural education are also faced with competing engagements in which 
they may choose to invest their time. Institutional policies can have an impact on how students devote their time and can impact their success (Astin, 1999).

The research related to school size and extracurricular participation is limited. Leithwood and Jantzi (2009) conducted a review of research and found only four studies published between 1996 and 2007 which found extracurricular participation to be higher among students in smaller schools (Coladarci \& Cobb, 1996; Crosnoe et al., 2004; Feldman \& Matjasko, 2007; McNeal, 1999). Since 2007, the research in this area continues to be limited. Regardless of school size consideration, SBAE teachers continually rate competences related to student involvement in programs including FFA program management, training teams, and administering programs as areas of considerable need for their own professional development (DiBenedetto et al., 2018).

\section{Purpose}

The purpose of the study was to explore how agriculture teachers in small schools in New Mexico developed their own institutional polices and worked with the polices established by the school to involve students in the FFA. The study was guided by the following overarching research question: How do agriculture teachers in small schools in New Mexico make their programs successful?

\section{Methods}

This qualitative study used case study methodology to explore how agriculture teachers in small schools in New Mexico implement agricultural education programs (Bronk, 2012; Merriam, 2002). Case studies allow researchers to provide a thick, rich description of how teachers in small programs implement their programs. According to Bronk(2012), an exemplar case study examines programs that exemplify a construct in a highly developed manor. This choice to highlight the exemplary programs as individual cases was supported by the research question.

For this study, the population was all SBAE teachers in small programs in New Mexico. Small programs were defined as those schools classified as ' $A$ ' according to the New Mexico Activities Association for basketball, which had less than 99 students enrolled in grades 9-12. There were 40 programs who qualified for this case, 24 of the programs had agricultural education programs. The sample for the study yielded six programs which were considered exemplary. These programs were determined to be exemplary because they engaged students in the total program of agricultural education and have achieved measures of success or recognition including peer recognition, service in leadership positions in teacher groups, or other forms of accomplishments. The state supervisor of agricultural education was asked to confirm these individuals met the criteria of the study.

Six teachers were identified, contacted, and all agreed to participate in the study. Semistructured interviews were conducted over the phone and recorded. In person interviews were 
not possible because of the remote nature of the programs and video conferencing was not feasible due to limited internet capabilities of some of the schools. The qualitative interview guide was developed to explore questions related to decisions teachers make in their programs. Questions were also asked to confirm the size of the program and to ensure they met terms of the exemplar case. The interviews lasted approximately one hour and all recordings were transcribed by hand by the research team. The research team included (a) an assistant professor in agricultural education, (b) a professor in extension education, and (c) an associate professor in agricultural leadership. Two of the researchers had a working relationship with the participants through agricultural education programming. The third researcher was involved in the data analysis portion including overseeing the dependability and confirmability audit to ensure the findings were connected to the data.

Results were reported using thick, rich descriptions of the participants to allow the reader to determine transferability to other settings (Creswell \& Miller, 2000). Investigator triangulation and member checks were employed to ensure trustworthiness (Lincoln \& Guba, 1985). Through the triangulation, two themes were combined, and the wording of the themes was refined. Member checks provided confirmation of the major themes. Data were analyzed through thematic analysis using open coding (Braun \& Clarke, 2006).

All six teachers had more than five years of teaching experience and their agricultural education student program involvement ranged from $17 \%$ to $86 \%$ of the total student population.

Pseudonyms were given to all participants. Angie had been teaching for 12 years total and 10 at her current school. Her school had a total of 44 students from 7th-12th grade, 38 of which were enrolled in her courses. Beth had been a teacher for ten years and has been in her role for just over a year. The school she worked in had 55 students total enrolled in 7th-12th grade, 36 of which were in her program. Casey had been a teacher for three years in the same program with five years of teaching experience. The school had 120 students from 7th-12th grade, of which 70 are enrolled in the agricultural education program. Daniel had been teaching for 25 years, 15 in his program. He has served in a leadership position in the agriculture teachers association. The town's population was 143 people. Because of the remote location of the town, students rode a bus from around 70 miles on either side of the school. There were 79 students enrolled in kindergarten (K)-12; 28 students in his program. Elenore had been teaching for 17 years in the same program. The school had 12 students enrolled in 7th-12th grade; eight were in the agriculture program. Tom taught in a program with 300 students from $\mathrm{K}-12$. There were 50 students in the agricultural education program. He had been teaching for 31 years and 20 years at the current school.

\section{Subjectivity Statement}

As a research team, we all have a passion for formal and nonformal education of agriculture and related topics. All three of us have taught in either the high school, non-formal, and higher education settings. However, none of us have had direct experience working in small programs as defined in this study. One member of the research team has nine years of work with schoolbased agricultural education programs. Another member of the research team has 32 years of non-formal education experience and has worked closely with school-based programs. Their 
research as faculty specifically focuses on supporting agricultural educators. While the third researcher did not teach in a formal agricultural secondary program, she is familiar with the context and brings her passion for rural communities to this work.

\section{Findings}

Theme 1: Small programs are unique. To be successful, programs must cater to the school and community context.

The first theme that emerged highlighted how small programs have nuanced differences compared to larger schools. One of the most prevalent differences is that the students in the school do multiple activities across the school programming. Tom noted, "In a small school, every kid plays ball. They're all going to play every sport, also in everything else that's in school, drama or our student council or anything else going on, cheerleading. Their time is very limited." They also engage in these many activities with their peers. Angie expressed this by saying, "The kids do everything together." This involvement creates a demand on student time.

Students in these rural areas also had familial obligations that do not mirror those of urban areas. In addition to the involvement in school, the students in these schools are expected to be involved in family ranches. According to Daniel,

The majority of the kids are ranch kids. When branding time comes, well, they're out of school for three or four days or when gathering comes, they're out of school for three or four days or [when] shipping comes, they're out of school for three or four days. They're expected to trabajar at the Rancho, you know?

Beth noted some of her students have a house nearby the school where they stay during the week, but go to the family ranch to work on the weekends, making engagement for weekend activities difficult. Elenore cast a different view of the ranching lifestyle of her students. She noted, "they kind of get ranching a little bit, but the parents don't really talk to them about it much. There's a difference between being raised on a ranch and understanding how ranches work."

The constant pull of involvement outside of school and multiple opportunities within school puts a strain on students. While providing opportunities to students, the constant pull can have negative effects. According to Angie "These kids do everything. They're exhausted. They're tired. We pushed them hard academically, they're pushed hard athletically. They don't have a break ever." Even though students are involved in a lot of activities, the agriculture program in these schools is typically the only option for elective courses. According to Angie, "I've kinda saturated my market. I mean, I'm the only elective and so I can count on one hand how many kids I don't have in program." Similarly, Elenore noted being one of two options students can choose for their elective courses.

Despite the demand on time, the teachers see the value of participation and communicate that value to students. Daniel urges the students to get involved. 
I tell them you live in [small town] America where the populations are 143 and most of those are old people like me, this is your chance to judge, do a little bit of work...get out of town and, and meet some people.

Angie similarly noted she hopes students will be, "willing to take risks" and "get out of their comfort zone," by trying new things in their program.

Even if students are committed to be involved in the agricultural education program, the size of these programs places limitations on the scope of the involvement. According to Elenore, "When you only have eight kids, you can't really run a lot of contests." Angie noted, "The kids are so busy. Sometimes I have to make decisions, but the kids just don't have time for that. They can't do that. That's one more thing. And is that really an important thing for our chapter?"

Despite the challenges of a small program, the benefits seem to outweigh the barriers. When comparing his experience working in a larger school, Daniel noted, "you go to a little school and you think I'm in The Bahamas or Tahiti. It takes as much work. But in reality, it doesn't take as much work. And you really, really appreciate that little school." An additional benefit of the size of the program is the close relationships of the students. According to Angie, "The school operates like a family." This family atmosphere extends beyond the school day. Daniel, for example, had students stay at his house that is next door to the school on a morning they were leaving early for a contest, so they did not have to leave at 4:30 a.m.

\section{Theme 2: Fostering relationships is essential for program success.}

A major theme emerged related to relationships, specifically relationships with administrators, coaches, and individuals in the communities. Every participant mentioned how both internal and external relationships are necessary for program success. According to Elenore, "Success is due to the relationship and support of others. I have really good support from my superintendent, and I have excellent support from our school board members and my fellow staff members and from our community." Likewise, Beth acknowledged the importance of parental support:

I have a very, really supportive group of parents right now. And that's a big part too know it starts at home with the parents pushing their kids to study or reminding the kids to make sure that kids can make practices and contests.

While establishing relationships may not be unique to small programs, there are some differences for small programs in rural New Mexico. According to Casey,

Everything from lifestyle or at the county fair to taking the kids on a conference, you got to build those as those relationships, both with the students and with the parents and the community. Because once you have that buy in from the communities that are more likely to send their younger brother, younger sister into your program, especially in such a small school. If mom and dad were in FFA back in their day, they're more likely to send their kids to FFA, now or they're going to encourage those kids to enter that project. Because of the small nature of the schools these programs operate in, there are demands for involvement which lead to relationship building opportunities amongst teachers. Angie noted 
the importance of being aware when other programs have events going on and not trying to work against them. She noted,

It's easy in a small program to put your blinders on and think your program's the only one, but it's going take a lot of steps back. These kids are trying to keep a lot of programs afloat and if you can recognize that and then work with those other programs instead of against them, I think the results are better.

Casey supported students in athletics by volunteering. According to Casey, I've always been a sports fan. So I approached the athletic director. I said, hey, if you need somebody to keep books or a clock or something for basketball games holler at me, I'm more than willing to help. I got to do every single basketball game. . . I'm able to show those kids. I support them through their other activities outside of FFA. I'm able to show their parents, you know, I'm not only your ag teacher, I'm also a, a strong supporter of your kid. I want them to be successful on and off the court. I want them to be successful in my shop, in my classroom.

Tom similarly noted that he helped with the athletic program. According to Tom, "[I] drive the bus for them a lot. Go to probably every basketball and football and volleyball game, I'm also the announcer at the games and stuff. So I'm very involved in sports. and the kids know it." This involvement helped to build relationships in the school as well as showing the students the teachers care about them beyond what they do in their agriculture courses. Casey worked to change the culture of the program, shifting from an 'either or' approach to a more inclusive one.

I've worked very closely with the athletic director because before I came here it was always you do basketball or you do FFA. There is no in between. There were exceptions to that rule of course, but that was kind of the culture. I have been working our athletic director and basketball coaches. We're too small of a school to make a kid choose. (Casey)

Beth noted,

In a small school you have to share your students and they're going to be, the kids that are involved in FFA are going to be the kids that are involved in everything else that's available at that school. So it's just really important to develop that relationship with the coaches and the parents so that you can make practices work, you can make contest work, otherwise your chapter, you're just going to kind of flail around. You're not going to get anything really done.

Although this cooperation was expressed as essential, there was one incident of a breakdown of relationship. Elenore reported competing against another program in her school. She stated, "The teacher that teaches the media program is equally as enthusiastic and in love with her program as I am with mine. And so sometimes the kids get a little pulled ... it's very challenging."

Several of the participants noted working early with the school to put FFA events on the calendar so teachers and coaches know when to expect students to miss time. Daniel and 
Elenore also noted bringing the school sports schedule to the agriculture teachers meeting to plan large FFA events at the state level. Elenore noted, "All of my FFA activities are already on our school calendar for next year. And the coach has already come to me the AD and asked me when my FFA events are and we don't fight about it."

The theme of using community support came up less frequently. Casey provided a vivid example of partnering with a veterinarian to work with the vet science team. According to Casey, "They come out once a week. They spend an hour, two hours with my kids this year and they, they try to bring live specimens for the kid to look at." Angie had a differing thought about community involvement noting challenges with delegating tasks and managing volunteers. Beth noted the benefit of community support programs make the program visible in the community so when they, "can continue to have that community support that we need financially and when we want to go do things like if you go to nationals."

\section{Theme 3: Student buy-in is required for success.}

Student buy-in was expressed to be required for program success by all participants. Elenore put this simply by stating, "You can't have a successful program without good kids." Several themes emerged related to strategies for gaining student buy-in. The most prevalent, was showing the students the teacher cares about them. The participants expressed the importance of being warm and open because the students can choose to be in their class or program. Even as the students in these small schools have limited options for elective courses, the teachers still work to create a warm environment for students. According to Daniel, "They can elect to take it or they can elect not to take it. And so, I'm not the grim reaper...I'm an entertainer. They have fun." Tom similarly noted, "It is an elective class. They don't have to be there. I had to give [them] a reason to want to come. I keep my classes fun. You know, I try to tell them first day of class, FFA means fun." There were also themes of focusing on high expectations for students. Beth noted, "I'm a very driven person and I expect a lot from my students. I have very high expectations and I hold their feet to the fire." She shared a story about her first year in the program when the students did not perform well at a state contest.

I made them all go to the awards ceremony even though we weren't anywhere near being on the board. And I say, we're going to sit through this and you're going to watch every single one of these kids that did well and worked hard walk across that stage and you're going to clap for them. And when we got home I said, how does that feel to sit there and watch every one of those kids walk across the stage? And they all agreed that it wasn't fun. So the next year I said, well next year you need to work really hard so that you guys are the ones walking across that stage.

While this direct approach can be effective, it is typically balanced with a more compassionate approach. Angie emphasized balance between caring and expectations. She stated,

To be able to build a program, we have [to have a] healthy student teacher relationship, because if you don't have a relationship with a student, then they don't want to work for you. .. . Because they know I care about them as a teacher, they're more likely to trust my judgment and want to want to work for me and please me. 
The teachers found success in providing opportunities where the students can feel accomplished in their work. According to Elenore, "you've got to make it where every single one of those kids feels valued and worth something in the program." Casey accomplished this by making his course and programmatic offering more diverse. He noted, "If I could diversify my curriculum a little bit more, I was able to retain those students who would have otherwise found family, consumer science or computer science or band." Casey continued to note he diversified his program by adding leadership and animal science components to his classes in addition to agriculture mechanics. Similarly, Angie noted working towards building a wellrounded program to value the students' interests. She did this by finding opportunities for students to get involved in areas other than career development events. According to Angie, "maybe it is event coordination, banquet coordination or community service ...or building things in the shop. For us, that's big." There were also mentions of being humble and open with the students. Daniel shared that when he started in the school, he offered humility to earn the respect of his students.

You see [the former teacher's] boots? I said, those are his boots right there. I had one of my boy's baby shoes I pulled out of my pocket. I said, these are my shoes right here. I'm not trying to fill his boots. I just want to grow into my own and we'll grow together.

\section{Advice and Best Practices}

The teachers were also asked to give advice and provide best practices for other teachers in small programs. First, participants expressed the need to be patient as they try to build a program. Several of the participants noted they were successful when they added things to their programs slowly and intentionally. Beth noted when she took over the program, there were 15 students doing 10 contests, and not doing any of them very well. "The next year I just paired it down I found a couple of people that could help teach me about the contest and paired it down and just gave them like five options" (Beth). Once she selected a hand full of contests, she told the students: "If you become really successful at these five contests, then we'll consider adding another contest."

Participants felt that the best advice for program management was to determine what was best to increase student engagement. The number of contests and how to determine how to choose them differed amongst the participants. Tom participated in the most contests working 11 teams. Daniel reported working with 4-8 contests per year depending on the student interest. Angie, Beth, and Casey reported training 4-6 teams with additional leadership development events at different times of the year. Elenore worked with 2-3 teams depending on the student interest. The participants chose their contests differently. Daniel and Casey reported providing sign-up sheets for all contests and identifying what the students wanted to do. Both Angie and Beth, focused on specific contests that matched what was taught in their program. When working the teams, the teachers all preferred in-person practices. Angie reported the most out of school hours in practice having hourlong practices starting at 6:00 a.m. and ending after school at 8:00 p.m. with a total of eight practice blocks for each team. Beth similarly noted dedicating an hour practice per week for each contest. Instead of individual practices, Tom held block practices in the afternoons after basketball practice where students would work on various contests independently. The teachers also noted varying strategies with structuring 
officer teams. Some teachers operated officer teams with constitutional positions, others utilized a full slate of officers and committee structures. Elenore noted that all students in program were essentially officers. Tom noted the positions on the parliamentary procedure team were the same as his officer position.

Finally, the participants offered additional advice related to seeking support from other agriculture teachers. The participants noted themes of seeking support and being able to help younger teachers. Casey, Beth, and Elenore mentioned using community resources and support to help. Beth noted her success as a beginning teacher was a result of reaching out to other teachers. She noted, "I reached out to the teachers that were more seasoned than me because I was first year teacher and just asked for help ... I went to workshops and tried to learn as much as I could."

\section{Conclusions, Discussion, and Recommendations}

Our study found that agricultural educators in New Mexico employed three main approaches for successful programming: catering programs to the school and community context, fostering supportive relationships, and developing student buy-in. At first glance, these themes are not surprising and could be recommended regardless of program size. However, where the themes come to life and hold substantive meaning is how these teachers execute these themes in their programs. When talking about their students, the participants did not talk about a lack of student engagement, supporting Leithwood and Jantzi's (2009) findings that students participate at higher levels in smaller schools. In fact, the teachers in these programs have to balance the issue of overworking the students. The teachers also noted the students tend to move in a uniform block rather than separating into identifiable groups. Teachers in small schools could benefit from making sure their offerings are diverse enough to meet the interest of students and fitting into the community context.

Relationships were deemed critical to program operation. Chief among these relationships was the interaction with those in charge of athletics in the school. The teachers in the study worked collaboratively to make sure the programs existed symbiotically. To facilitate this relationship, we suggest teachers in small schools work to foster a healthy relationship with both internal and external stakeholders. Spending time to get to know the context of the school and community would greatly support student's program engagement. A theme emerged related to student buy-in being important for success. These teachers worked to build support for students through a careful balance of warm, fun openness and high expectations of hard work. Developing this balance could be difficult, especially for someone stepping into a new role in a small school. Further research could illuminate how teachers establish and maintain this balance with their students.

We also inquired about best practices and advice for successful programs. A consensus did not exist for specific aspects of program management including number of teams, types of practices, and methods for selecting officer teams. Ultimately, participants felt that teachers 
needed to approach program management in the ways that best suited their personal preferences and those of the students. This study provides an example of what works for successful programs in rural New Mexico and can provide some insight into small programs in other states. We recommend that teachers carefully consider the context as they make decisions on how to offer components of agricultural education programs. We also recommend that agriculture teachers in small schools find ways to work with fellow school staff, stakeholders, and students to make programming decisions. Carefully integrating these decisions will make the most of students' commitment of time beyond the classroom, which is needed for successful programs (Talbert et al., 2014)

Student involvement theory seeks to explain how students engage in programs (Astin, 1999). The findings of this study show students in these small schools are active in most opportunities that are available to them. Perhaps because they have fewer opportunities, they felt compelled to participate. A qualitative investigation from the student's perspective could illuminate the student decision making process related to participation in school programming. Important questions for future investigation could focus on the appropriate level of time commitment for students, as well as working with student to develop time-management strategies. The unique context of agricultural education programs at small schools warrants specific consideration. Decisions related to delivery of agricultural education programs and FFA events at state and national levels should consider how those decisions will impact programs with low numbers of students.

\section{References}

Astin, A. W. (1999). Student involvement: A developmental theory for higher education. Journal of College Student Development, 40(5). https://www.middlesex.mass.edu/ace/downloads/astininv.pdf

Braun, V., \& Clarke, V. (2006). Using thematic analysis in psychology. Qualitative Research in Psychology, 3(2), 77-101. https://doi.org/10.1191/1478088706qp063oa

Bradley, S., \& Taylor, J. (2001). The effect of school size on exam performance in secondary schools. Oxford Bulletin of Economics and Statistics, 60(3), 291-324. https://doi.org/10.1111/1468-0084.00102

Bronk, K.C. (2012). The exemplar methodology: An approach to studying the leading edge of development. Psychology of Well-Being: Theory, Research and Practice, 2(5). https://doi.org/10.1186/2211-1522-2-5

Coladarci, T., \& Cobb, C. D. (1996). Extracurricular participation, school size, and achievement and self-esteem among high school students: A national look. Journal of Research in Rural Education, 12(2), 92-103 https://jrre.psu.edu/sites/default/files/2019-08/122 8.pdf 
Creswell, J. W., \& Miller, D. L. (2000). Determining validity in qualitative inquiry. Theory into Practice, 39(3), 124-130, https://doi.org/10.1207/s15430421tip3903 2

Croom, D. B. (2008). The development of the integrated three-component model of agricultural education. Journal of Agricultural Education, 49(1), 110-120. https://doi.org/10.5032/jae.2008.01110

Crosnoe, R., Johnson, M. K., \& Elder, G. H. (2004). School size and the interpersonal side of education: An examination of race/ethnicity and organizational context. Social Science Quarterly, 85(5), 1259-1274. https://doi.org/10.1111/j.0038-4941.2004.00275.x

DiBenedetto, C. A., Willis, V. C., \& Barrick, R. K. (2018). Needs assessment for school-based agricultural education teachers: A review of literature. Journal of Agricultural Education, 59(4), 52-71. https://doi.org/10.5032/jae.2018.04052

Feldman, A. F., \& Matjasko, J. L. (2007). Profiles and portfolios of adolescent school-based extracurricular activity participation. Journal of Adolescence, 30(2), 313-332. https://doi.org/10.1016/i.adolescence.2006.03.004

Foreman-Peck, J. \& Foreman-Peck, L. (2006). Should schools be smaller? The size-performance relationship for Welsh schools. Economics of Education Review, 25(2), 157-171. https://doi.org/10.1016/j.econedurev.2005.01.004

Lavalley, M. (2018). Out of the loop. National School Boards Association Center for Public Education. https://cdn-files.nsba.org/s3fs-public/109015071 CPE_Rural School_Report_Web_FINAL.pdf

Leithwood, K., \& Jantzi, D. (2009). A review of empirical evidence about school size effects: A policy perspective. Review of Educational Research, 79(1), 464-490. https://doi.org/10.3102/0034654308326158

Lincoln, Y. S., \& Guba, E. G. (1985). Naturalistic inquiry. Sage Publications

McNeal, R. B. (1999). Participation in high school extracurricular activities: Investigating school effects. Social Science Quarterly, 80(2), 291-309. http://www.jstor.org/stable/42863901

Merriam, S., \& Tisdell, E. J. (2016). Qualitative research: A guide to design and implementation (4th ed.). John Wiley and Sons.

National Center for Educational Statistics. (2020). Digest of education statistics. https://nces.ed.gov/programs/digest/current tables.asp

National FFA Organization. (n.d.). Agricultural Education: About FFA. https://www.ffa.org/agricultural-education/ 
Newcomb, L. H., McCracken, J. D., Warmbrod, J. R., \& Whittington, M. S. (2004). Methods of teaching agriculture (3rd ed.). Pearson/Prentice Hall.

Rumberger, R. W., \& Thomas, S. L. (2000). The distribution of dropout and turnover rates among urban and suburban high schools. Sociology of Education, 73(1), 39-67. https://doi.org/10.2307/2673198

Sawkins, J. W. (2002). Examination performance in Scottish secondary schools: An ordered logit approach. Applied Economics, 34(16), 2031-2041.

https://doi.org/10.1080/00036840210124559

Talbert, B. A., Vaughn, R., Croom, B., \& Lee, J. S. (2014). Foundations of agricultural education (3rd ed.). Pearson Education, Inc.

(C) 2022 by authors. This article is an open access article distributed under the terms and conditions of the Creative Commons Attribution license (http://creativecommons.org/licenses/by/4.0/). 